\title{
KAJIAN KUALITAS TERJEMAHAN TINDAK TUTUR YANG MENGANDUNG IMPLIKATUR PADA FILM THE PIRATES OF CARIBBEAN: THE CURSE OF THE BLACK PEARL (2003), DEAD MAN CHEST (2006), DAN AT THE WORLD'S END (2007)
} (Sebuah Kajian Terjemahan dengan Pendekatan Pragmatik)

\author{
Karlina Widyastuti ${ }^{1}$, M. R. Nababan ${ }^{2}$, Djatmika ${ }^{2}$ \\ ${ }^{1}$ Program Studi Linguistik, Pascasarjana, Universitas Sebelas Maret, Surakarta \\ ${ }^{2}$ Universitas Sebelas Maret, Surakarta \\ 1lina.astoety@gmail.com
}

\begin{abstract}
This article is a descriptive qualitative study oriented in translation products analyzing the translation of conversational implicature in the Pirates of Caribbean movie series: The Pirates of Carribean: The Curse of the Black Pearl (2003), Dead Man Chest (2006), and At the World's End (2007) through pragmatic approach. The aims of this study are: 1) to identify the types of illocutions as well as the maxims involved; 2) to map pragmatic force shift in the translation of implicatures found in the movies; 3) to describe translation techniques applied in translating the implicatures found in the movies; 4) to describe the influence of translation techniques towards the pragmatic force shift that might happen; and 5) to describe the quality of translation of the implicatures found in the movies. The data used in this research was collected from the dialogue between the actors of the movies through several methods, such as content analysis, questioner and indirect interview. Meanwhile, data used to analyze the quality of translation was collected through the assessment and scoring that has been done by the raters. Subtitler might translate utterances that contain implicature in the dialogue into implicature or explicates its illocutionary force. Any choices the subtitler made -and any translation techniques that hel she choose, affected the quality of the subtitle. Situational as well as audio-visual context also need to be considered during the translation process to obtain high quality subtitle. In this research, there are four types of speech act found; assertive, directive, expressive, and commissive. It is found that the shift of pragmatic force happened in some of data which applied literal translation, discursive creation, and addition techniques in its translation process. The shifts affected its translation quality in the aspect of accuracy, however in it was found that it did not affect its acceptability.
\end{abstract}

Keywords : translation, translation techniques, implicature, subtitle, pragmatic force shifting, translation quality, accuracy, acceptability.

\section{PENDAHULUAN}

Suatu komunikasi dinyatakan berhasil apabila pesan yang ingin disampaikan dapat ditangkap maknanya oleh mitra tutur. Namun tidak jarang, pesan tersebut tidak tercermin dalam kalimat yang diucapkan. Seseorang yang mengatakan 'Makanan sudah siap' tidak 
hanya bermaksud memberi informasi tentang makanan yang dihidangkan, tetapi penutur memiliki pesan tersirat bahwa dia mempersilahkan lawan bicaranya untuk menikmati makanan tersebut, atau jika percakapan tersebut berlangsung di sebuah dapur restoran dan penutur adalah seorang koki, maka pesan yang ingin disampaikan adalah penutur mempersilahkan pelayan untuk menghidangkan makanan tersebut kepada tamu yang memesannya. Makna tersirat yang terdapat dalam kalimat percakapan itulah yang disebut dengan implikatur.

Fenomena implikatur tersebut tidak hanya terjadi dalam percakapan sehari-hari dalam kehidupan nyata, namun acapkali muncul pula dalam dialog-dialog yang diucapkan oleh aktor/ aktris dalam sebuah film ataupun drama. Berikut contoh implikatur yang terdapat dalam film The Pirates of Caribbean: The Curse of the Black Pearl.

Jack : Will you saving her, then?

Officer 1 : I can't swim.

Subtitle merupakan ringkasan terjemahan tertulis dari dialog asli yang muncul sebagai baris-baris teks yang biasanya terletak di bagian bawah layar. Subtitle muncul dan menghilang bertepatan dengan waktu dialog tersebut diucapkan. Dengan kata lain, bahasa verbal yang diucapkan oleh tokoh-tokoh atau narator dalam film atau tayangan tersebut dialihkan kedalam bentuk teks atau tulisan. Teks tersebut dipotong-potong dan disesuaikan kemunculannya dengan waktu pengucapan dialog untuk kemudian diletakkan di bagian bawah layar.

Dalam hubungannya dengan implikatur yang terdapat pada dilaog film, tugas seorang penerjemah (subtitler) adalah menyampaikan maksud tersembunyi sebuah ujaran bahasa sumber ke dalam bahasa tulis pada bahasa sasaran karena kesalahan dalam memahami katakata maupun struktur gramatika bahasa sumber sangat mungkin mempengaruhi hasil terjemahan implikatur tersebut (Baker, 1991: 229).

Ulvydienè dan Aleknavičiūtė menggunakan serta menghubungkan variabel-variabel strategi penerjemahan audio-visual yang digagas oleh Zoe Pettit (2009) dengan maksimmaksim Grice (1975) yang terdapat dalam film. Penelitian tersebut didasarkan pada hipotesis bahwa strategi penerjemahan maksim kualitas berhubungan dengan penerjemahan literal dan replacement, maksim kuantitas dengan omission dan explicitation, maksim cara dengan strategi borrowing dan generalization, dan maksim hubungan dengan strategi equivalence dan adaptation.Sumardiono (2011) pada hasil akhir penelitiannya, menyimpulkan bahwa terjadi pergeseran daya pragmatik pada sebagian terjemahan ujaran yang mengandung 
implikatur. Pergeseran tersebut terjadi karena teknik penambahan, penghapusan, dan eksplisitasi yang diterapkan. Teknik yang digunakan tersebut juga berpengaruh pada kualitas hasil terjemahan. Putranti (2007) mengkaji tindak ilokusi ekspresif yang terdapat dalam film serta terjemahan bahasa Indonesianya. Hasil penelitiannya membuktikan bahwa sebagian besar terjemahan tindak tutur dalam film berterima, namun keberterimaan tersebut tidak selalu ditentukan oleh kesepadanan makna antara $\mathrm{BSu}$ dan BSa. Terjemahan yang tidak sepadan, namun didukung oleh tayangan visualnya dapat menjadikan terjemahan tersebut berterima. Terjemahan dikatakan tidak berterima apabila tidak didukung tayangan visual atau bahkan ketika dialog tidak diterjemahkan sama sekali. Berdasarkan celah - celah yang didapatkan dari penelitianpenelitian mengenai kualitas penerjemahan implikatur dalam film diatas, penelitian ini akan membahas teknik penerjemahan yang digunakan untuk menerjemahkan implikatur percakapan yang terdapat dalam film The Pirates of Caribbean: The Curse of the Black Pearl (2003), Dead Man Chest (2006), dan At The World's End (2007) serta dampak penggunaan teknik tersebut terhadap pergeseran daya pragmatik dan kualitas terjemahannya. Penelitian ini mengambil film sebagai objek penelitian karena dalam penerjemahan subtitle terdapat batasan-batasan yang dapat mempengaruhi penerjemah dalam mengambil keputusan.

Secara umum, tujuan penelitian ini untuk menganalisis ujaran yang mengandung implikatur yang terdapat dalam film The Pirates of Caribbean: The Curse of the Black Pearl, Dead Man Chest, dan At The World's End dan subtitle bahasa Indonesia-nya. Namun secara khusus, tujuan penelitian ini adalah untuk 1) mengidentifikasi jenis tindak tutur bermuatan implikatur -serta maksim-maksim yang terlibat; 2) mengidentifikasi dan mengkaji teknikteknik yang diterapkan dalam penerjemahan tindak tutur yang mengandung implikatur; 3) mendeskripsikan pengaruh teknik penerjemahan terhadap pergeseran daya pragmatik dalam terjemahan tindak tutur yang mengandung implikatur; dan 4) mendeskripsikan tingkat keakuratan dan keberterimaan terjemahan ujaran yang mengandung implikatur pada subtitle film dalam kaitannya dengan pergeseran daya pragmatik dan teknik penerjemahan yang diterapkan 


\section{TEORI DAN METODOLOGI}

\section{Penerjemahan}

Secara umum, penerjemahan dipahami sebagai proses pengalihan pesan dari bahasa sumber (Bsu) ke dalam bahasa sasaran (Bsa). Nida \& Taber (1982: 12) menjelaskan bahwa "translation consists of reproducing in the receptor language the closest natural equivalence of the source language message, first in the terms of meaning and secondly in terms of style”. Terkait dengan kesepadanan makna, Newmark (1988: 5) mengatakan bahwa konsep dasar penerjemahan adalah “...rendering the meaning of a text into another language in the way that the author intended the text". Sementara terkait dengan perubahan bentuk, Larson (1984: 2) menyatakan bahwa pada dasarnya dalam suatu penerjemahan, perubahan bentuk dalam struktur permukaan (surface structure) tidak dapat dihindarkan karena adanya perbedaan karakteristik antara Bsu dan Bsa. Sedangkan makna atau pesan adalah struktur dalam (deep structure).

Baker (1992: 11) menyatakan bahwa "...there is no one-to-one correspondence between orthographic words and elements of meaning within or across languages". Satu kata yang disampaikan dalam suatu bahasa mungkin perlu disampaikan dalam bentuk frasa, klausa, atau bahkan kalimat dalam bahasa lain. Lebih lanjut, Baker membahas kesepadanan tidak hanya dalam tataran kata saja tetapi lebih tinggi yakni, tataran diatas kata (collocation, idiom, fixed expression), gramatikal, tekstual, dan bahkan dalam tataran pragmatik.

Dari pendapat-pendapat diatas dapat disimpulkan bahwa penerjemahan tidak hanya sekedar mengalihkan bentuk bahasa sumber ke dalam bentuk bahasa sasaran karena kedua bahasa tersebut pada umumnya berbeda dalam hal struktur kebahasaannya. Lebih jauh, ada sesuatu yang lebih penting yang harus dipertahankan dalam proses penerjemahan, yakni kesepadanan pesan atau makna dari teks bahasa sumber, dan lebih dalam lagi, daya pragmatik yang mungkin terdapat dalam bahasa sumber.

Menurut Nababan (2008: 24) proses penerjemahan dapat diartikan sebagai serangkaian proses kegiatan mengalihkan pesan dari bahasa sumber ke bahasa sasaran yang dilakukan oleh seorang penerjemah. Proses tersebut sangat dipengaruhi oleh kompetensi yang dimiliki oleh penerjemah.Proses penerjemahan diawali dengan mengidentifikasi leksikon, struktur gramatikal, situasi komunikasi dan konteks struktur 
teks bahasa sumber; menganalisis untuk mendapatkan makna teks tersebut;dan merekonstruksi makna yang sama dengan menggunakan leksikon dan struktur gramatika yang sesuai dan berterima dalam bahasa sasaran (Larson, 1984: 2). Suryawinata (2003: 20) menambahkan satu tahapan dalam proses penerjemahan, yakni evaluasi dan revisi.

Teknik penerjemahan merupakan prosedur untuk menganalisis dan mengklasifikasikan bagaimana kesepadanan terjemahan berlangsung dan dapat diterapkan pada berbagai satuan lingual (Nababan, 2010: 6). Molina \& Albir (2002) mendefinisikan teknik penerjemahan sebagai prosedur-prosedur untuk menganalisa serta mengklasifikasikan cara mencari padanan dalam penerjemahan. Teknik penerjemahan memiliki lima karakteristik dasar, yakni; 1) mempengaruhi hasil terjemahan; 2) dikelompokkan berdasarkan perbandingan dengan teks asli Bsu; 3) mempengaruhi unit mikro dalam teks; 4) diskursif dan kontekstual; serta 5) fungsional.

Molina \& Albir (2002) mengklasifikasikan teknik penerjemahan menjadi 18 jenis, yakni: adaptation, amplification, borrowing, calque, literal translation, compensation, description, discursive creation, established equivalent, generalization, particularization, linguistic amplification, linguistic compression, modulation, reduction, substitution, transposition, variation.

Pentingnya penilaian kualitas terjemahan disebabkan oleh dua hal; 1) untuk menciptakan hubungan dialektik antara teori dan praktek penerjemahan, dan 2) untuk kepentingan kriteria dan standar dalam menilai kompetensi penerjemah (Machali, 2009: 142). Penilaian kualitas terjemahan terkait dengan pemikiran bagaimana mengetahui baik atau tidaknya sebuah terjemahan.Machali (2009: 145) menyatakan bahwa yang perlu diingat dalam penilaian penerjemahan bukanlah sekedar dari segi benar-salah, bagus-buruk, harfiah-bebas. Ada beberapa segi dalam penerjemahan yang harus dipertimbangkan dalam menilai kualitas suatu hasil terjemahan. Nababan (2010: 3) menyebutkan ada tiga parameter dalam menilai kualitas terjemahan, yakni; 1) keakuratan (accuracy), 2) keberterimaan (acceptability), 3) keterbacaan (readability).

\section{Penerjemahan Audiovisual}

Cintas (2009: 4) menyebutkan bahwa tiga besar bentuk penerjemahan audiovisual yang sering digunakan, yakni dubbing, voiceover, dan subtitling. Penelitian ini 
membahas salah satu dari bentuk penerjemahan audiovisual diatas, yakni subtitling. Dalam Encyclopedia of Television, subtitling diartikan sebagai

"The written translation of the spoken language (source language) of a television program or film into the language of the viewing audience; the translated text usually appears in twolines at the foot of the screen at the same time that thedialogue or narration in the source language is heard."

Bartoll (dalam Branchadell \& West, 2004: 53) menjelaskan bahwa Gottlieb (1997) mengklasifikasikan subtitle berdasarkan dua perspektif berbeda, yakni perspektif linguistik dan perspektif teknis. Dalam perspektif linguistik, subtitle dibedakan menjadi dua yaitu:Intralingual subtitle atau hanya melibatkan satu bahasa saja dan Interlingual subtitling yang melibatkan dua bahasa. Sementara secara teknis, O’Connell (2007: 125126) membedakan subtitle menjadi: OpenSubtitledanClosed Subtitle. Sumber data penelitian ini didapat dari open subtitle yakni yang menyatu dengan film.

Skuggevik dalam Cintas \& Anderman (2009: 198) menyebutkan lima level atau tingkat kompetensi yang harus dikuasai oleh seorang subtitler, yaitu:

1. kompetensi teknis, berhubungan dengan kemampuan teknis seperti pengaturan letak subtitle, penggunaan huruf, penyesuaian durasi waktu, dan lain sebagainya;

2. kompetensi linguistik, yakni pemahaman kebahasaan baik bahasa sumber maupun bahasa sasaran;

3. kompetensi budayayakni pemahaman penerjemah terhadap aspek-aspek sosial dan budaya (non linguistic) serta hubungan antara kedua aspek tersebut dengan dialog yang diucapkan;

4. memiliki pemahaman tentang dimensi psikologis dan emosional yang melekat dalam tindakan para aktornya yang menyertai dialog;

5. kemampuan menggabungkan keempat level sebelumnya dan menggunakannya dalam menentukan strategi penerjemahan yang diperlukan berdasarkan batasanbatasan yang ada dalam subtitle, untuk mendapatkan hasil terjemahan sesuai dengan yang diinginkan

\section{Pragmatik}

Yule (1996) menyatakan bahwa pragmatik adalah sebuah studi tentang makna yang disampaikan oleh penutur -atau penulis, dan ditafsirkan oleh pendengar -atau pembaca (penerjemah: Wahyuni, 2006: 3). Tidak hanya sebatas kajian tentang makna saja, lebih 
jauh Searle, Kiefer, dan Bierwich (1980) dalam Nadar (2009: 4) menegaskan bahwa pragmatik berkaitan dengan interpretasi suatu ungkapan yang dibuat berdasarkan aturan sintaksis tertentu dan cara penginterpretasian ungkapan tersebut tergantung pada kondisi khusus saat ungkapan tersebut digunakan dalam konteks.

Austin (1962: 98-99) dalam Nadar (2009: 11) menyebutkan bahwa pada dasarnya pada saat seseorang mengatakan sesuatu, dia juga melakukan sesuatu. Contohnya ketika seseorang berkata I'm sorry, sesungguhnya orang tersebut selain mengatakan tuturan juga melakukan tindakan meminta maaf. Lebih lanjut, Austin (dalam Thomas, 1995: 49) membagi tindak tutur menjadi: 1) tindak lokusi, yakni tuturan yang menyatakan sesuatu, 2) tindak ilokusi, yakni daya atau maksud yang menyertai tuturan tersebut, dan 3) tindak perlokusi, yakni pengaruh tindak ilokusi tersebut terhadap mitra tutur.

Brown dan Yule (1996 : 31) menyatakan bahwa istilah implikatur dipakai untuk menerangkan apa yang mungkin diartikan, disarankan, atau dimaksudkan oleh penutur yang berbeda dengan apa yang sebenarnya yang dikatakan oleh penutur. Grice (dalam Thomas, 1995: 57) membedakan dua jenis implikatur yakni: conventional implicature danconversational implicatureatau implikatur percakapan. Data yang digunakan dalam penelitian ini adalah conversational implicature.

Nababan (1987:28) mendefinisikan implikatur percakapan sebagai suatu konsep yang dipakai untuk menerangkan perbedaan yang sering terdapat antara 'apa yang diucapkan' dengan 'apa yang diimplikasikan'. Cruse (2000: 37-38) menyebutkan empat ciri conversationalimplicature, yakni: a. Context Dependence, memiliki ketergantungan pada konteks; b. Defeasibility/ Cancellability; c. Non-Detachablity; dan d. Calculability.

Grice (1975:45-47) mengemukakan bahwa suatu percakapan yang wajar dapat terjadi apabila antara penutur dan petutur patuh pada prinsip kerjasama komunikasi. Terdapat empat maksim dalam prinsip kerjasama, yaitu: maksim kualitas (the maxims of quality), maksim kuantitas (the maxims of quantity), maksim hubungan (the maxims of relation), dan maksim cara (the maxims of manner). Dalam suatu percakapan, tidak selamanya penutur dan mitra tutur selalu mematuhi dan memenuhi maksim-maksim tersebut. Ketidaktaatan tersebut dibedakan menjadi 1) Flouting a maxim, 2) Violating a maxim, 3) Infringing a maxim, 4) Opting out of a maxim, 5) Suspending a maxim (Thomas, 1995: 64). 
Leech (1983) dan Wijana (1996) dalam Nadar (2009: 29) menyatakan bahwa dalam suatu interaksi, para pelaku memerlukan prinsip lain selain prinsip kerjasama, yaitu prinsip kesopanan (politeness principle). Prinsip kesopanan juga memiliki sejumlah maksim, yaitu (Nadar, 2009: 30-31): maksim kebijaksanaan (tact maxim), maksim kemurahan (generosity maxim), maksim penerimaan (approbation maxim), maksim kerendahan hati (modesty maxim), maksim kecocokan (agreement maxim), maksim kesimpatian (sympathy maxim).

Newmark (1988: 133) menyatakan bahwa “...one's purpose in translating it is to be referentially and pragmatically accurate." dengan kata lain, tujuan seseorang menerjemahkan adalah akurat baik secara referensi maupun secara pragmatik. Akurat secara pragmatik disini erat kaitannya dengan readership atau pembaca. Diharapkan, suatu karya terjemahan mampu memberikan efek pragmatis terhadap pembaca seperti yang ada dalam karya aslinya.Dengan demikian, dapat disimpulkan bahwa dalam penerjemahan, pendekatan pragmatik memungkinkan seorang penerjemah mampu memahami dan kemudian mengungkapkan makna sesuai yang dimaksudkan oleh penulis (atau pembicara) yang didukung oleh konteks yang menyertainya ke dalam bahasa sasaran.

\section{Metode Penelitian}

Penelitian ini merupakan penelitian bidang penerjemahan yang berfokus pada produk terjemahan, merupakan penelitian kualitatif deskriptif, bersifat etnografi, dan merupakan penelitian terpancang (embeddedresearch).Penelitian yang berorientasi pada produk adalah penelitian yang memusatkan perhatiannya pada tingkat keakuratan pengalihan pesan dan tingkat keterbacaan teks terjemahan (Nababan, 2003). Data yang digunakan dalam penelitian ini adalah percakapan yang mengandung implikatur pada film The Pirates of Caribbean: The Curse of the Black Pearl, Dead Man's Chest, dan At World's Endyang diproduksi oleh Walt Disney Pictures dan diedarkan di Indonesia oleh PT. Vision Interprima Pictures dan data nilai kualitas dan keberterimaan yang didapat dari para informan atau rater. Rater yang menilai kualitas hasil terjemahan dipilih berdasarkan kriteria-kriteria tertentu sebagai berikut:

1. Memiliki kompetensi yang memadai dalam bidang penerjemahan (teori dan praktek) 
2. Menguasai bahasa Inggris dan bahasa Indonesia

3. Memahami dengan baik konsep implikatur dalam pragmatik

\section{HASIL DAN PEMBAHASAN}

\section{Jenis tindak tutur bermuatan implikatur serta maksim-maksim terlibat}

Pada penelitian ini ditemukan empat jenis tindak tutur yang bermuatan implikatur yang terdapat pada film The Pirates of Caribbean: The Curse of the Black Pearl, Dead Man Chest, dan At The World's End. Tindak tutur tersebut yakni; tindak tutur asertif sebanyak 82 ujaran, tindak tutur direktif sebanyak 18 ujaran, tindak tutur ekspresif sebanyak 20 ujaran, dan tindak tutur komisif sebanyak 5 ujaran.

Pada ujaran asertif, ditemukan 19 jenis ilokusi tak langsung yaitu: memberi informasi, membual, memohon, menerangkan, mengecam, mengeluh, mengiyakan, mengkritik, menolak, menolak memberi informasi, menyanggah, menyarankan, menyatakan, menyatakan alasan, menyatakan ketidaksetujuan, menyatakan ketidaktahuan, menyatakan pendapat, menyatakan persetujuan, dan meyakinkan. Dari ke 19 ilokusi tersebut, ilokusi tak langsung menolak merupakan ilokusi tak langsung yang paling banyak ditemukan yakni sebanyak 12 ujaran, diikuti oleh ilokusi tak langsung menyatakan sebanyak 10 ujaran. Ujaran dengan ilokusi mengiyakan dan memberi informasi juga cukup banyak ditemukan dengan masing-masing berjumlah 8 dan 9 ujaran. Berikut beberapa contoh temuan data dengan implikatur asertif:

BSU Will : Where's the rest of the crew?

Gibbs : These cages we're in weren't built 'till after we got here.

BSA Will : Dimana sisa awak yang lain?

Gibbs : Kurungan kita ini dibuat setelah kami mendarat.

Konteks situasi menunjukkan Will ditawan oleh suku Pelegostos bersama dengan awak kapal the Black Pearl didalam kurungan yang terbuat dari tulang manusia dan digantung diatas jurang. Gibbs menjelaskan bahwa suku primitif tersebut menjadikan Jack sebagai pimpinan mereka dan menganggapnya sebagai Dewa yang terperangkap dalam wujud manusia. Untuk membebaskannya, suku Pelegostos akan membakar Jack dan memakan tubuhnya. 
Dalam teks bahasa sumber, jawaban yang diberikan oleh Gibbs mengandung implikatur karena jawaban tersebut tidak menyatakan sesuatu secara langsung, seperti misalnya "They are all dead, killed (and eaten) by the tribe. This cages was made by their bones". Jawaban Gibbs mengandung lokusi menyatakan namun daya ilokusi yang ingin disampaikan adalah Gibbs ingin memberi informasi kepada Jack bahwa awak kapal yang lain telah mati. Gibbs melanggar maksim hubungan demi memenuhi maksim simpati untuk menghormati awak kapal yang telah dibunuh oleh suku Pelegostos.

Pada teks terjemahan, jawaban Gibbs, "Kurungan kita ini dibuat setelah kami mendarat"sama seperti ujaran dalam bahasa sumber. Ujaran ini mengandung implikatur asertif dengan daya ilokusi memberi informasi. Pelanggaran maksim hubungan terjadi karena Gibbs ingin memennuhi maksim simpati. Dengan demikian tidak terjadi pergeseran daya pragmatis yang berupa perubahan daya ilokusi antara bahasa sumber dan bahasa sasaran.

Ujaran yang mengandung implikatur asertif dengan ilokusi tak langsung menerangkan ditemukan pada data 36/TCBP/CD2 yang merupakan percakapan antara Jack dan Will.

BSU Will : That's not true, I am not obsessed with treasure.

Jack : Not all treasure is silver and gold, mate.

BSA Will : Itu tak benar. Aku tak terobsesi harta karun.

Gibbs : : Tak semua harta karun berupa perak dan emas, sobat.

Jack dan Will menaiki sekoci menuju pulau Isla de Muerta tempat Barbossa dan anak buahnya membawa Elizabeth. Jack mengatakan bahwa walaupun Will secara terus terang menyatakan bahwa dia membenci perompak, namun pada kenyataannya dia sudah berperilaku seperti perompak, membebaskan orang dari penjara, mencuri kapal, dan berlayar dengan perompak. Ketika mereka melihat emas di dasar pantai, Jack mengatakan bahwa Will juga terobsesi pada harta karun. Will memprotes pendapat terakhir Jack. Setelah mereka sampai di gua, Jack berkata bahwa tidak semua harta karun berupa emas dan perak.

Dalam bahasa sumber, respon yang diutarakan oleh Jack mengandung implikatur asertif dengan ilokusi tak langsung menerangkan karena pernyataan ini juga 
mengandung pesan lain yang ingin disampaikan oleh Jack kepada Will. Jack ingin menyampaikan pada Will bahwa dia terobesesi dengan Elizabeth sehingga rela melakukan apa saja untuk membebaskannya. Kalimat yang diucapkan oleh Jack melanggar maksim cara karena kalimat tersebut terkesan ambigu dan tidak jelas. Melalui konteks situasi dapat disimpulkan bahwa ujaran Jack tersebut berimplikasi "What I mean is that you are obsessed with Elizabeth". Dalam terjemahan bahasa sumbernya kalimat Jack diterjemahkan menjadi "Tak semua harta karun berupa perak dan emas, sobat". Terjemahan tersebut juga mengandung implikatur asertif dengan ilokusi tak langsung menerangkan sehingga dalam hal ini tidak terjadi pergeseran daya pragmatis.

Dalam temuan data ujaran direktif, jenis ilokusi tak langsung nya terbagi menjadi tindak tutur dengan ilokusi tak langsung melarang (1), memerintah (13), meminta (1), memohon (1), dan mengajak (2). Berikut data temuan yang merupakan implikatur direktif:

Elizabeth Norrington

Governor Swann

Norrinton

BSA Elizabeth Norrington

Governor Swann

Norrinton
: I think it would be rather exciting to meet a pirate.

: Think again, Miss Swann. Vile and dissolute creatures, a lot of them. I intend to see to it that any man who sails under a pirate flag or wears a pirate brand gets what he deserves, a short drop and a sudden stop.

\section{: Lieutenant Norrington, I appreciate your fervor, but} I'm, uh... I'm concerned about the effect this subject will have upon my daughter.

: My apologies, Governor Swann.

: Menurutku bertemu dengan perompak menyenangkan.

: Pikirkan baik-baik lagi, Nn. Swann. Mereka sangat busuk dan kejam. Akan kupastikan setiap orang di kapal berbendera perompak pakai tanda perompak akan terima hukuman. Mereka tak akan selamat.

: Letnan Norrington, kuhargai bantuanmu. Tapi aku mencemaskan pengaruh pembicaraan ini pada puteriku.

: Maafkan aku, Gubernur Swann

Konteks situasi percakapan tersebut diatas kapal yang membawa mereka ke Port Royal untuk pertama kalinya. Sebelumnya, Elizabeth kecil menyanyikan lagu tentang perompak, salah satu anak buah Norrinton memperingatkan Elizabeth bahwa menyanyikan lagu tentang perompak dipercaya membawa nasip buruk, termasuk membawa perempuan ke atas kapal. Namun, Elizabeth justru mengatakan bahwa 
bertemu perompak merupakan hal yang menyenangkan. Letnan Norrington menyanggah hal tersebut kemudian mengingatkan tentang kekejaman perompak kepadanya dan apa yang akan dia lakukan apabila bertemu dengan mereka. Gubernur Swann merasa keberatan dengan hal tersebut.

Kalimat Gubernur Swann "Lieutenant Norrington, I appreciate your fervor, but I'm, uh... I'm concerned about the effect this subject will have upon my daughter." Sejatinya merupakan sebuar larangan. Dengan kalimat tersebut Gubernur memerintahkan Norrington untuk menghentikan pembicaraan mengenai perompak. Bisa jadi, Gubernur Swann tidak ingin Elizabeth kecil mendengar cerita lebih jauh mengenai kekejaman perompak ataupun hal mengerikan tentang pembunuhan, hukuman gantung, dan hal mengerikan lainnya. Namun, disisi lain, bisa jadi Gubernur Swann berbuat hal tersebut dikarenakan, cerita-cerita tersebut akan semakin menambah ketertarikan Elizabeth serta memicu rasa ingin tahunya. Bagi seorang gadis kecil keturunan bangsawan, tentu saja hal tersebut sangat tidak pantas. Sekilas, Gubernur Swann tampak melanggar maksim cara: be brief, dengan memenuhi prinsip kesopanan yakni maksim pujian: minimize dispraise to other. Gubernur Swann tidak ingin bersikap tidak sopan kepada Norrington yang merupakan kapten kapal tersebut. Dia tidak ingin Norrington merasa kehilangan muka dihadapan anak buahnya. Kalimat Gubernur Swann tersebut berimplikasi "Lieutenant Norrington, stop this conversation related to pirates! It will bring bad effects to my daughter."

Dalam bahasa Indonesia, kalimat "Letnan Norrington, kuhargai bantuanmu. Tapi aku mencemaskan pengaruh pembicaraan ini pada puteriku." Bisa dikatakan juga merupakan implikatur direktif dengan ilokusi tak langsung memerintah. Dengan kalimat tersebut Gubernur Swann ingin Norrington menghentikan pembicaraan mengenai perompak karena hal tersebut akan berpengaruh buruk bagi Elizabeth. Tidak terjadi pergeseran daya pragmatis dalam penerjemahan ini.

Sementara itu, dari 20 ujaran tindak tutur ekspresif, digolongkan menjadi sembilan (9) tindak ilokusi tak langsung, yakni: menggoda, menyatakan keheranan, menyatakan kekecewaan, menyatakan kekesalan, menyatakan kemarahan, menyatakan keprihatinan, menyatakan ketidakpedulian, menyatakan ketidakpercayaan, menyatakan ketidaksukaan. Ujaran dengan tindak ilokusi tak langsung yang mengandung ilokusi tak langsung menyatakan kemarahan merupakan tindak ilokusi yang paling banyak 
ditemukan dalam tindak tutur ekpresif pada penelitian ini. Berikut contoh data temuan yang merupakan implikatur ekpresif:

BSU Elizabeth : I just thought I'd be married by now. I'm so ready to be married.

Jack :You know...uhm, Lizzie, I'm Captain of a ship and being captain of a ship I could, in fact, perform a marriage right here. Right on this deck. Right...now.

BSA Elizabeth : Aku memikirkan bahwa saat ini seharusnya aku sudah menikah. Aku sudah sangat siap untuk menikah.

Jack

: Kau tahu...Lizzie, aku kapten sebuah kapal, dan sebagai kapten kapal, aku bisa menikah di sini.Di atas geladak ini. Sekarang juga.

Elizabeth dan Jack berada diatas kapal the Black Pearl dalam perjalanan mengejar kapal the Flying Dutchman yang membawa Will. Elizabeth yang terlihat bersedih memberitahu Jack bahwa seharusnya dia sudah menikah dan dia benar-benar sudah siap menikah. Di awal cerita, digambarkan batalnya pernikahan antara Elizabeth dan Will disebabkan adanya perintah penangkapan atas mereka.

Dalam bahasa Inggris, komentar Jack "You know...uhm, Lizzie, I'm Captain of a ship and being captain of a ship I could, in fact, perform a marriage right here. Right on this deck. Right...now. "merupakan implikatur ekspresif yang berilokusi tak langsung menggoda. Tentu saja Jack tidak bersungguh-sungguh dengan ucapannya, karena dalam adegan sebelumnya diperlihatkan bagaimana Jack mengatakan kepada Elizabeth bahwa dia telah memberikan seluruh hidupnya pada laut yang bisa diartikan bahwa Jack tidak berniat untuk menikah dan terikat dengan siapapun. Kalimat Jack tersebut hanya dimaksudkan untuk menggoda Elizabeth yang mengatakan bahwa dia sebenarnya sudah sangat siap menikah. Jack melanggar maksim cara: be brief. Kalimat Jack tersebut bisa diasumsikan berimplikasi "If you are ready to get married, you can marry me now".

Dalam bahasa Indonesia, kalimat Jack "Kau tahu...Lizzie, aku kapten sebuah kapal, dan sebagai kaptel kapal, aku bisa menikah di sini. Di atas geladak ini. Sekarang juga." Juga merupakan implikatur karena sekilas melanggar maksim cara. Ujaran ini dimaksudkan untuk menggoda Elizabeth. Tidak terjadi pergeseran daya pragmatis dalam penerjemahan ini. 
Pada lima tindak tutur komisif yang ditemukan, diantara ilokusi mengancam, menawarkan, dan berjanji, tindak tutur dengan ilokusi tak langsung mengancam merupakan ilokusi yang paling banyak (3 ujaran).

\section{Teknik penerjemahan yang diterapkan dalam penerjemahan tindak tutur yang} mengandung implikatur

Pada penelitian ini, ditemukan tidak hanya varian teknik tunggal, tetapi juga ditemukan pula proses penerjemahan dengan menggunakan dua teknik atau yang lazim disebut kuplet, tiga teknik atau triplet, dan empat teknik atau kuartet.

Sebagian besar data yang ditemukan diterjemahkan menggunakan varian tunggal, yakni sebanyak 100 buah data atau sebanyak 80\% dari keseluruhan data. Ditemukan sepuluh (10) jenis teknik penerjemahan yang digunakan yakni teknik literal translation (42), reduction (22), discursivecreation (11), modulation (8), addition (5), transposition (6), establishedequivalent (2), amplification (1), linguisticcompression (1), particularization (1).

Pada teknik penerjemahan kuplet penerjemah menggabungkan dua teknik dalam proses penerjemahan subtitle yang mengandung implikatur dalam tiga judul film thePirates of Carribean. Ditemukan 21 data atau sebanyak $16.8 \%$ dari keseluruhan data yang menggunakan varian teknik penerjemahan ini. Sebanyak sebelas (11) gabungan dua teknik ditemukan dalam penelitian ini. Pada penerapan teknik kuplet ini, gabungan teknik amplification + reduction dan discursivecreation + reduction yang paling banyak digunakan yakni masing-masing ditemukan lima ujaran. Sedangkan penerapan varian teknik penerjemahan triplet dan kuartet masing-masing ditemukan sebanyak satu ujaran dan tiga ujaran. Dari keseluruhan teknik penerjemahan yang digunakan -termasuk varian kuplet, triplet dan kuartet, teknik literaltranslationmerupakan teknik yang paling banyak digunakan yakni sebanyak 42 ujaran.

\section{Pergeseran daya pragmatis yang timbul dalam penerapan teknik penerjemahan}

Dalam penelitian ini ditemukan adanya pergeseran daya pragmatis atau ilokusi yang ditimbulkan dalam ujaran yang mengandung implikatur pada bahasa sasaran. Dari 125 data yang ditemukan, sebanyak 6 data mengalami persegeran daya pragmatis atau sebanyak 4,8\% dari keseluruhan data. 
Ujaran yang mengalami pergeseran tersebut diakibatkan oleh penerapan teknik addition, discursive creation, dan literal. Dari temuan data yang mengalami pergeseran, penerapan teknik kreasi diskursif paling banyak digunakan, yakni sebanyak 3 data atau $50 \%$ dari keseluruhan data yang ditemukan. Berikut temuan data yang mengalami pergeseran daya pragmatis dalam terjemahannya. Data tersebut terdapat dalam percakapan antara Sao Feng dan Mercer. Sao Feng memprotes keputusan Mercer bawahan Beckett, yang menempatkan tentara angkatan laut diatas kapal the Black Pearl. Ujaran Mercer ketika menanggapi protes Sao Feng merupakan implikatur dengan ilokusi tak langsung memerintah yang berimplikasi "Diam. Kapal ini milik East Indian Trading Company, begitupun dengan kru-nya. Kau tak berhak protes”.

BSU

Sao Feng Mercer

BSA

$$
\begin{array}{ll}
\text { Sao Feng } & : \text { Orangku sangat terlatih. } \\
\text { Mercer } & \text { : Kapal dan awak Company. }
\end{array}
$$

: My men are crew enough.

: Company ship, company crew.

Penambahan kata "dan" dalam kalimat bahasa sasaran telah menghilangkan daya ilokusi tak langsung 'memerintah' pada bahasa sumber. Penambahan tersebut menyebabkan ujaran yang disampaikan oleh Mercer menjadi sebuah kalimat tidak utuh yang tidak memiliki makna implikasi apapun. Alternatif terjemahan yang dapat digunakan yakni "Kapal Company, ABK tentara Company". Alternatif terjemahan tersebut dipilih mengacu pada batasan-batasan dalam subtitle. Tanpa adanya batasanbatasan tersebut, alternatif lain dapat dipilih sehingga menghasilkan terjemahan yang lebih akurat dan berterima. Misalnya "Kapal milik Company, awak kapal tentara Company".

Pergeseran yang timbul dari penerapan teknik tersebut disebabkan kurang cermatnya penerjemah dalam menelaah ujaran dan menganalisa keterpaduan antara ujaran dan koteks situasi -termasuk dalam hal ini konteks audio-visual, pada saat ujaran tersebut diucapkan.

\section{Kualitas terjemahan dalam kaitannya dengan teknik penerjemahan yang digunakan dan pergeseran daya pragmatis yang timbul akibat teknik tersebut.}

Penelitian ini mengukur dua aspek kualitas terjemahan yakni tingkat keakuratan dan keberterimaan dari ujaran yang mengandung implikatur pada subtitle tiga film 
Pirates of Carribean: The Curse of the Black Pearl, Dead Man's Chest, dan At the World's End. Penulis melibatkan enam rater dengan masing-masing aspek melibatkan tiga rater berbeda -salah satunya adalah peneliti, untuk mendapatkan informasi yang obyektif.

Dari 125 ujaran yang masuk ke dalam data, sebagian besar data terjemahan masuk ke dalam skala 3 atau bisa dikategorikan memiliki tingkat keakuratan yang tinggi. Ratarata tingkat keakuratan dalam subtitle ketiga film ini adalah 2,87. Dari seluruh data, 111 data atau $88,8 \%$ merupakan terjemahan yang akurat, tiga belas (13) data dengan terjemahan kurang akurat atau sebanyak $10,4 \%$ dan hanya ada satu (1) data -atau $0,8 \%$ dari seluruh data, yang termasuk dalam kategori terjemahan tidak akurat. Data yang masuk ke dalam kategori tidak akurat dipengaruhi oleh teknik penerjemahan kreasi diskursif. Dari tiga belas data dengan terjemahan kurang akurat, presentase penggunaan teknik kreasi diskursif juga dilihat paling menonjol, yaitu sebanyak lima ujaran. Dari lima ujaran tersebut, tiga diantaranya mengalami pergeseran daya pragmatis. Dua dari tiga terjemahan ujaran tersebut dinilai kurang akurat dan bahkan satu data dinilai tidak akurat.

Sementara itu, dari aspek keberterimaan ditemukan bahwa hampir seluruh terjemahan telah memenuhi nilai/ kaidah bahasa dan budaya Indonesia. Tingkat keberterimaan terjemahan ujaran yang mengandung implikatur bernilai rata-rata 2,97. Dari keseluruhan data 125 data, sebanyak 124 data -atau 99,2\%, termasuk dalam kategori berterima, dan hanya ada satu (1) -atau 0,8\%, data yang masuk kategori kurang berterima. Tidak ditemukan data yang termasuk dalam kategori tidak berterima.

\section{SIMPULAN}

Secara umum dapat disimpulkan bahwa teknik penerjemahan yang digunakan untuk menerjemahkan ujaran yang mengandung implikatur pada film Pirates of Carribean: The Curse of the Black Pearl, Dead Man's Chest, dan At the World's End memberi dampak yang baik terhadap kualitas terjemahan terutama pada aspek keakuratan dan keberterimaannya. Hal tersebut dapat dilihat dari presentase tingkat keakuratan dan keberterimaannya. Pergeseran daya pragmatis yang timbulakibat penerapan teknik penerjemahan tidak memberikan pengaruh yang signifikan terhadap keseluruhan 
kualitas terjemahan karena dilihat dari hasil temuan, secara umum penerjemah dinilai telah mampu mentrasfer makna implisit yang ada dalam bahasa sumber.

\section{DAFTAR PUSTAKA}

Baker, M. (1992). In other words: A course book on translation. London: Routledge.

Bartoll, E. (2004). Parameters for the classification of subtitles. dalam Topics in Audiovisual Traslation ed. Pilar Orero. Philadelphia: John Benjamin Publishing Company.

Bittner, H. (2011). The quality of translation in subtitling. trans-kom 4 [1] (2011): 7687.

Blaxter, L., C. Hughes, \& M. Thight. (2006). How to research methods: an introduction to qualitative and quantitative approaches. Thousand Oaks: Sage Publication.

Bungin, B. (2007). Penelitian kualitatif. Jakarta: Kencana Prenada Media Grup.

Catford, J.C. (1965). A linguistic theory of translation. Oxford: Oxford University Press.

Cintas, G.D., \& Gunilla Anderman. (2009). Audiovisual translation: language transfer on screen. Hampshire: Palgrave Macmillan.

Cruse, A. (2006). A glossary of semantics an pragmatics.Edinburgh: Edinburgh University Press.

Dearbon, F. (2004). Encyclopedia of television vol. 4. New York: Fitzroy Dearbon Publishers.

Desilla, L. (2009). Towards a methodology for the study of implicatures in subtitled films: multimodal construal and reception of pragmatic meaning across cultures. Desertation. Manchester: University of Manchester (http://www.llc.manchester.ac.uk/ctis/phd/completed_phd/desilla/)

Georgakopoulou, P. (2009). Subtitling for the DVD industry. hlm. 21-25 dala, Cintas \& Anderman (ed.) Audiovisual translation: language transfer on screen. Hampshire: Palgrave Macmillan.

Grice, H. P. (2004). Logic and conversation. London: University College London for Pragmatic Theory Online Course .

Hariyanti, S. (2001). Implikatur percakapan dalam prosa fiksi bahasa Inggris (suatu kajian pragmatik). Tesis. Surakarta: UNS.

Hatim, B., \& Mason, I. (1997). The translator as communicator. New York: Routledge. 
Hickey, L. (1998). The pragmatics of translation; topics in translation 12. Clevedon: Multilingual Matters.

Karamitlogou, F. (1997). A proposed set of subtitling standards in Europe. Dipublikasikan pada Accurapid Journal vol. 2, no. 2, April 1998.

Kao, H.L. (2011). Coherence in Subtitling. Theses. New Castle University.

Larson, M. L. (1984). MeaningbBased translation (Penerjemahan berdasar makna: pedoman untuk pemahaman antar bahasa - penerjemah. Kencanawati). Jakarta: ARCAN.

Leech, G.N. (1983). Prinsip-prinsip pragmatik (diterjemahkan oleh M.D.D. Oka \& Setyadi Setyapranata. 2011). Jakarta: Penerbit Universitas Indonesia.

Levinson, S.C. (1991). Pragmatics. Cambridge: University Press.

Machali, R. (2000). Pedoman bagi penerjemah. Jakarta: PT Grasindo.

Maxwell, J. A. (2010). Using numbers in qualitative research. Qualitative Inquiry. Sage Publication.

Moleong, L. J. (2002). Metodologi penelitian kualitatif. Jakarta: Remaja Karya.

Molina, L. \& Albir, H. (2002). Translation techniques revised: a dynamic and functionalist approach. dalam Meta: Journal des Traducteur/ Meta: Translation Journal. XLVII, No. 4 hlm. 498-512 .

Nababan, M.R. (2008). Teori menerjemah bahasa Inggris. Yogyakarta: Kanisius.

Nababan, M.R. (2010). Pengembangan model penilaian kualitas terjemahan. Ringkasan hasil penelitian HIKOM tahun II.

Nababan, M.R., et al. (2012). Pengembangan model kualitas terjemahan dalam Jurnal Kajian Linguistik dan Sastra, Vol. 24, No. 1., Juni 2012, 39-57.

Nababan, P.W.J. (1987). Ilmu pragmatik (teori dan penerapannya). Jakarta: Departemen Pendidikan dan Kebudayaan.

Nadar, F.X. (2009). Pragmatik \& penelitian pragmatik. Yogyakarta: Graha Ilmu.

Newmark, P. (1988). A textbook of translation. New York: Prentice Hall.

Newmark, P. (1988). Pragmatic translation and literalism. dalam Erudit, transduction, terminologie, redaction, vol. 1, no. 2, 1988. p. 133-145.

Nida, E. A.,\& Taber, C. (1974). The theory and practice of translation. Leiden:

E.J.Brill. 
O'Connell, E. (2007). Screen translation dalam A companion to translation studies. ed. Piotr Kuhizwack \& Karin Littau. Clevedon: Multilingual Matters Ltd.

Purnomo, SF. L.A., \& Untari, L. (2011). Asyiknya bikin subtitle!. Yogyakarta: Gosyen Publishing.

Putranti, A. (2007). Kajian terjemahan tindak ilokusi ekspresif dalam film American Beauty. Tesis. Surakarta: UNS.

Shuttleworth, M., \& Cowie, M. (1997). Dictionary of translation studies. Manchester: St. Jerome Publishing.

Sumardiono. (2011). Kajian terjemahan ujaran yang mengandung implikatur pada novel the Da Vinci Code (sebuah tinjauan pragmatik pada penerjemahan). Tesis. Surakarta: UNS.

Suryawinata, Z., \& Hariyanto, S. (2007). Translation: Bahadan Teori \& Penuntun Praktis Menerjemahkan. Yogyakarta. Penerbit Kanisius.

Sutopo, H. B. (2006). Metodologi penelitian kualitatif: dasar teori dan terapannya dalam penelitian. Surakarta: Sebelas Maret University Press.

Thomas, J. (1995). Meaning in interaction: an introduction to pragmatics. Edinburgh: Longman Group Limited.

Widyani, A. (2012). Analisis teknik, metode, ideologi penerjemahan film Lap Year versi VCD resmi dan versi Blog Rizal Adam. Tesis. Surakarta: UNS.

Yule, G. (1996). The Study of Language: Second Edition. Great Britain. Cambridge University Press. 